\title{
Determinant Factors of Diseases Suffering Duration among Elderly in Bangladesh
}

Md. Nuruzzaman Khan* and Md. Nazrul Islam Mondal

Department of Population Science and Human Resource Development, University of Rajshahi, Rajshahi-6205, Bangladesh

*Corresponding author: Khan MN, Department of Population Science and Human Resource Development, University of Rajshahi, Rajshahi-6205, Bangladesh, Tel: +880 721-75004; E-mail:sumonrupop@gmail.com

Received date: December 15, 2014; Accepted date: April 28, 2015; Published date: May 07, 2015

Copyright: ( 2015 Khan MN, et al. This is an open-access article distributed under the terms of the Creative Commons Attribution License, which permits unrestricted use, distribution, and reproduction in any medium, provided the original author and source are credited.

\author{
Abstract \\ Objective: This study aimed to identify the determinant factors of disease suffering duration among elderly \\ population in the rural areas of Bangladesh.
}

Methods: A cross-sectional study was conducted in three villages of Pabna District, Bangladesh. Data were collected from 250 (males, 168; females, 82) elderly aged 60 years and above using a structured questionnaire. To analyze the data, both bivariate and multivariate analyses were used as the statistical tools.

Findings: The results revealed that most of the elderly $(70.00 \%)$ were suffered from various types of long duration (>1 year) diseases. Respondents' age, partnership status, family type, family size, education, working status, family income, and drug addiction were found significantly associated with diseases suffering duration. Finally, the binary logistic regression model identified almost all the factors are as important predictors diseases suffering duration.

Conclusion: Health problems were found more prevalent among males than that of females. To reduce the disease suffering duration of the elderly, emphasis should be given to improve their financial condition and traditional family bond, and to create workplaces where they may involve.

Keywords: Age; Health problems; Education; Life expectancy

\section{Introduction}

Population aging is a process of increasing the number of persons aged 60 years and over and it is often considered as the global public health success. The age structure of world population has been experiencing the significant change during the period 1950-2013. The number of aging population increasing rapidly and the proportion of children and youth population are decreasing. In 1950, the number of world aged population was about 200 million, constituting $8.10 \%$ of the global population. Now, it is 841 million constituting $11.70 \%$ and it will be doubled by 2050 and constituted $21.10 \%$ of total global population [1]. Aging has started earlier in the developed countries and beginning a health issue in some developing countries like Bangladesh [2]. Now, Bangladesh is passing throughout the third stage of demographic transition which produces huge numbers of youthful and elderly population. As a small country of 1,47,570 sq. km land area Bangladesh [3] is the 8th largest and one of the most densely populated $(1,101$ persons/sq. $\mathrm{km})$ country in the world [4]. During the years 1974-2013, in Bangladesh the number of aged population has been increased from 1.38 million to 10.05 million and placed 122 ranked in the globe [1]. The rapidly increasing number and diversity of elderly, Bangladeshis has far-reaching implications for public health system and will place unprecedented demands on aging services and the nation's entire healthcare system. The increased elderly population consequences problems like physical and mental health along with the social and economic burdens [5]. In addition, the increasing proportion of landless population, changes in life styles, and rural to urban migration lead to smaller families put the elderly into more vulnerable situation [6-8]. Importantly, the vulnerability of elderly population reflected to the higher burden of ill health and disability and they have received a little attention from primary healthcare services [9]. On the other hand, elderly persons in better health may have a longer life expectancy than those in poorer health. In this regard, higher gross national income and availability of healthcare resources are prerequisite factors for longer life expectancy [10-13].

Research works on elderly have traditionally been focused on demographic factors $[2,8,14,15]$ social problems, [16,17] economic burdens, $[18,19]$ healthcare services, $[20,21]$ and disabilities [22,23]. However, relatively a few research works have investigated the determinant factors affecting on the diseases suffering duration of elderly. Therefore, this study aimed to identify the determinant factors which are responsible for disease suffering duration of elderly in the rural areas of Bangladesh. The authors hope that this study will be very helpful in identifying the risk factors of disease suffering duration and the findings will help the policy makers and researchers to determine how to reduce the duration of diseases of the elderly.

\section{Data and Methods}

Data and necessary information were collected from 250 (males, 168 ; females 82 ) elderly 60 years and above. Face to face interview was conducted from May 20 to June 15, 2013 in three villages of Malonchi Union in Pabna District, Bangladesh. Respondents were interviewed using purposive sampling technique through a structured 
Page 2 of 5

questionnaire. In univariate analysis, the percentage distribution of demographic and socioeconomic and disease related characteristics are presented in tables. The bivariate analysis $\left(\chi^{2}\right.$-test) was used to determine the significant associations between socioeconomic, demographic and health related factors with disease suffering duration. In multivariate analysis, binary logistic regression model was used to evaluate the effects of some factors contributed to disease suffering duration (dependent variable, Y). The underlying multiple logistic regression models corresponding to each variable are:

$$
\begin{gathered}
\log \frac{P}{1-P}\left(=\beta_{0}+\beta_{1} X_{1}+\beta_{2} X_{2}+\beta_{3} X_{3}+\beta_{4} X_{4}+\beta_{5} X_{5}+\beta_{6} X_{6}+\right. \\
\beta_{7} X_{7}+\beta_{8} X_{8} \rightarrow(1)
\end{gathered}
$$

where, $P$, the probability of long duration disease suffering ( $>1$ year) (coded 1) and 1-P, the probability of short duration disease suffering ( $\leq 1$ year) (coded 0$) ; X_{i}, i=1,2, \ldots . .8$ are the explanatory variables; $\beta_{\mathrm{o}}$, the intercept term, and $\beta_{\mathrm{i}}, \mathrm{i}=1,2, \ldots . .8$ are the unknown logistic regression coefficients. The parameter $\beta_{\mathrm{i}}$ refers to the effects of $\mathrm{X}_{\mathrm{i}}$ on the log odds such that $\mathrm{Y}=1$, controlling the other $\mathrm{X}_{\mathrm{i}}$. There is an important assumption in multiple regressions, either linear or logistic, that there is no multi-collinearity problem (dependent each to other) among the independent variables. However, there is no exact method to detect the multi-collinearity problem in multiple logistic regression analysis. In this study, the magnitude of the standard error (SE) was used to detect the multi-collinearity problem, if the magnitude of the SE lies between 0.001 and 0.5 , it is judged that there is no evidence of multi-collinearity [24]. In binary logistic regression model (Equation $1)$, eight explanatory variables with categories shown in parenthesis; age (X1) (year) $(60-70,1 ;>70,2)$, current partnership status (X2) (yes, 1; otherwise, 0), type of family (X3) (single family, 1; joint family, 2), family size (X4) $(\leq 5,1 ;>5,2)$, education (X5) (illiterate, 0 ; literate, 1$)$, present working status (X6) (no, 0 ; yes, 1), monthly family income (X7) (Taka) ( $\leq 6000,1 ;>6000,2)$, and any form of drug addiction (X8) (no, 0; yes, 1). Statistical Package for Social Sciences (SPSS) version 16.0 (SPSS Inc., Chicago, IL, USA) was used for statistical analysis.

\section{Results}

Univariate, bivariate and multivariate approaches have been applied in the analysis. The results are presented in the subsequent sections.

\section{Univariate analysis}

The background statistics of the elderly were presented in Table 1. Among the total elderly populations, $82(32.80 \%)$ were females and $168(67.20 \%)$ were males. The results revealed that most of the elderly (79.60\%; males, $77.38 \%$; females, $84.14 \%$ ) were found in the age group $\leq 70$ year. Almost all elderly (81.20\%; males, $89.29 \%$; females, $64.63 \%$ ) were leading the formal partnership lives. More than half elderly (52.80\%; males, $51.79 \%$; females, $54.88 \%$ ) were lived in the nuclear families. The economic status of elderly was considered their monthly family income and found that almost all were lived in the low income family ( $84 \%$; monthly family income, $6,000 \mathrm{Tk}$ or less). It is also found that most of the respondents $(56.40 \%)$ have had a smaller amount ( $\leq$ 100 decimal) cultivated land, and lived in clay made houses (62.80\%).

The percentage distributions of health-related characteristics by sexes of the elderly are presented in Table 2 . The results revealed that almost all elderly $(84.40 \%)$ were having health problems and these health problems were found more prevalent among males (86.90\%). In case of disease types, the elderly were suffered from different types of diseases, viz., Arthritis, Insomnia, Joint pain, Diabetics, etc. Among these diseases, Insomnia (45.97\%; males, 39.04\%; females, $48.78 \%$ ) and eye problem (44.55\%; males, $24.66 \%$; females, $39.02 \%$ ) we found more prevalent. In case of treatment costs, usually their sons (47.20\%) bear it, and also the elderly accompanied their sons (43.20\%) when they were sick. The elderly were demanded more family care and proper treatment. A few elderly (20.40\%) go to the registered doctors when

\begin{tabular}{|c|c|c|c|c|}
\hline \multirow[b]{2}{*}{ Characteristics } & \multirow[b]{2}{*}{$\begin{array}{c}\text { Covariate } \\
\text { s }\end{array}$} & \multicolumn{2}{|c|}{ Gender } & \multirow[t]{2}{*}{ Total } \\
\hline & & Male $(n=168)$ & $\begin{array}{c}\text { Female } \\
(n=82)\end{array}$ & \\
\hline \multirow[t]{2}{*}{ Age (year) } & $60-70$ & $130(77.38)$ & 69 (84.14) & $199(79.60)$ \\
\hline & $>70$ & $38(22.62)$ & $13(15.84)$ & $51(20.40)$ \\
\hline \multirow{2}{*}{ Religion } & Islam & $167(99.40)$ & 79 (96.34) & $246(98.40)$ \\
\hline & Others & $1(0.60)$ & $3(3.66)$ & $4(1.60)$ \\
\hline \multirow{2}{*}{$\begin{array}{l}\text { Life partnership } \\
\text { status }\end{array}$} & $\begin{array}{l}\text { Having } \\
\text { partner }\end{array}$ & $150(89.29)$ & $53(64.63)$ & $203(81.20)$ \\
\hline & Others & $18(10.71)$ & $29(35.37)$ & $57(18.80)$ \\
\hline \multirow{2}{*}{ Family type } & Nuclear & $87(51.79)$ & $45(54.88)$ & $132(52.80)$ \\
\hline & Joint & $81(48.21)$ & $37(45.12)$ & $118(47.20)$ \\
\hline \multirow{2}{*}{ Family size } & $\leq 5$ & $91(54.17)$ & $41(50.00)$ & $132(52.80)$ \\
\hline & $>5$ & $77(45.83)$ & $41(50.00)$ & $118(47.20)$ \\
\hline \multirow{2}{*}{$\begin{array}{l}\text { Monthly family } \\
\text { income (Taka) }\end{array}$} & $\leq 6000$ & $146(86.90)$ & $64(78.05)$ & $210(84.00)$ \\
\hline & $>6000$ & $22(13.10)$ & $18(21.95)$ & $40(16.00)$ \\
\hline \multirow{2}{*}{ Education } & Illiterate & $97(57.74)$ & $53(64.63)$ & $150(60.00)$ \\
\hline & Literate & $71(42.26)$ & $29(35.37)$ & $100(40.00)$ \\
\hline \multirow{2}{*}{$\begin{array}{l}\text { Having cultivated } \\
\text { land (decimal) }\end{array}$} & $\leq 100$ & $91(54.17)$ & $50(60.98)$ & $141(56.40)$ \\
\hline & $>100$ & $77(45.83)$ & $32(39.02)$ & $109(43.60)$ \\
\hline \multirow{2}{*}{ Housing condition } & Clay made & $106(63.09)$ & $51(62.20)$ & $157(62.80)$ \\
\hline & Others & $62(36.91)$ & $31(37.80)$ & $93(37.20)$ \\
\hline
\end{tabular}
they were sick.

Table 1: Distribution of socioeconomic condition by genders of elderly, $(\mathrm{N}=250)$. Note: The numbers inside the parenthesis indicate

\begin{tabular}{|c|c|c|c|c|}
\hline \multirow[b]{2}{*}{ Characteristics } & \multirow[b]{2}{*}{ Covariates } & \multicolumn{2}{|c|}{ Gender } & \multirow[b]{2}{*}{ Total } \\
\hline & & Male $(n=168)$ & $\begin{array}{c}\text { Female } \\
(n=82)\end{array}$ & \\
\hline \multirow{2}{*}{$\begin{array}{l}\text { Having health } \\
\text { problems }\end{array}$} & Yes & $146(86.90)$ & $65(79.27)$ & $211(84.40)$ \\
\hline & No & $22(13.10)$ & $17(20.73)$ & $39(15.60)$ \\
\hline \multirow{5}{*}{$\begin{array}{l}\text { Types of Health } \\
\text { problems* }\end{array}$} & Arthritis & $53(36.30)$ & $17(20.73)$ & $70(33.18)$ \\
\hline & Insomnia & $57(39.04)$ & $40(48.78)$ & $97(45.97)$ \\
\hline & Joint pain & $42(28.77)$ & $11(13.41)$ & $53(25.12)$ \\
\hline & Diabetes & $24(16.44)$ & $18(21.95)$ & 42(19.91) \\
\hline & Eye problem & $62(24.66)$ & 32(39.03) & $94(44.55)$ \\
\hline
\end{tabular}
the percentages. 
Citation: Md Khan N and Md Mondal NI (2015) Determinant Factors of Diseases Suffering Duration among Elderly in Bangladesh. Aging Sci 3:

Page 3 of 5

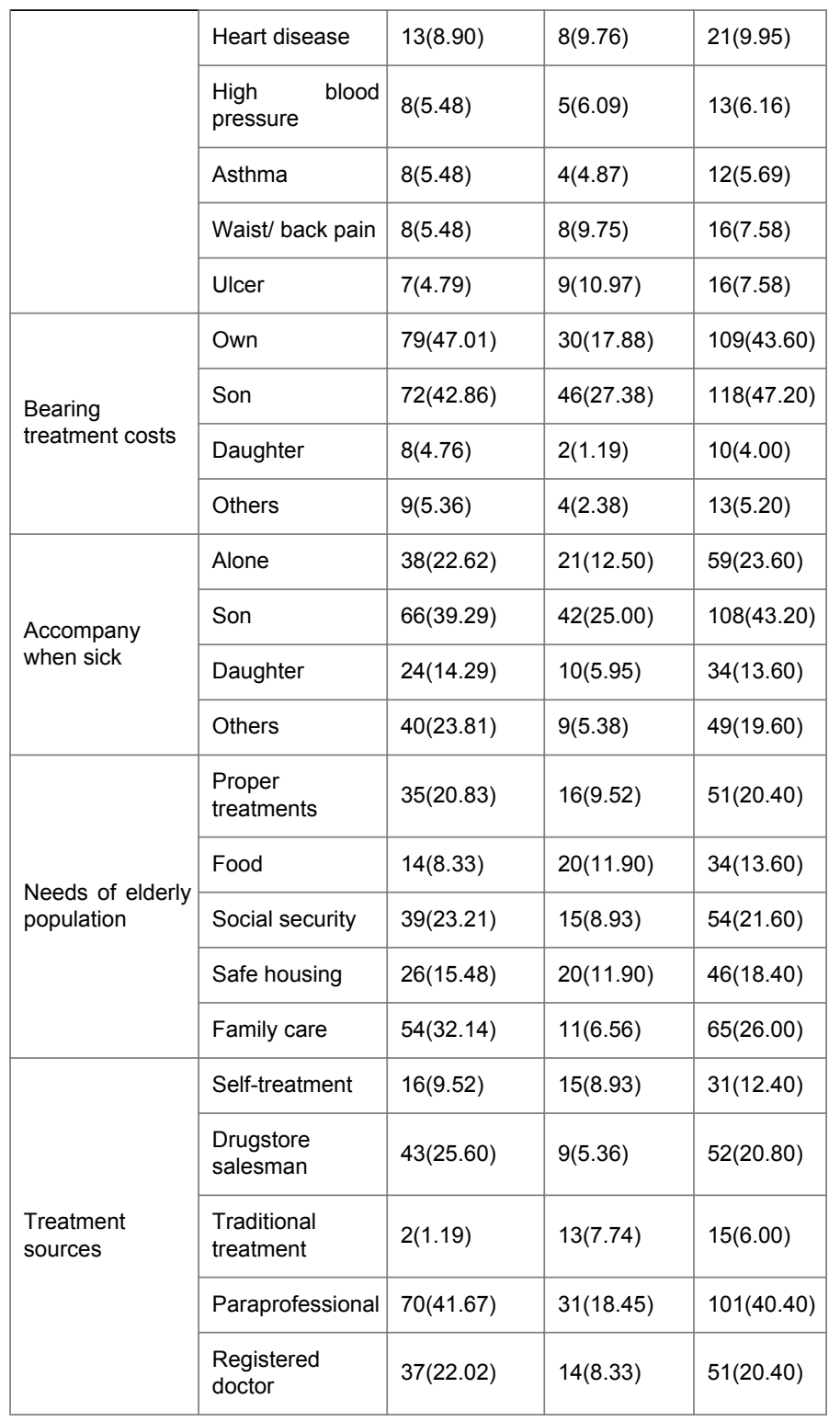

among the elderly aged $>70$ years, males, not have life partners, living in nuclear family, having less family members, illiterate, workless, lower family income, and drug addiction.

\begin{tabular}{|c|c|c|c|c|c|}
\hline \multirow[b]{2}{*}{$\begin{array}{c}\text { Characteristi } \\
\text { cs }\end{array}$} & \multirow[b]{2}{*}{ Covariates } & \multicolumn{2}{|c|}{$\begin{array}{l}\text { Disease suffering } \\
\text { duration }\end{array}$} & \multirow[b]{2}{*}{ Total } & \multirow[b]{2}{*}{$P$ values } \\
\hline & & $\begin{array}{c}\leq 1 \text { year } \\
(n=75)\end{array}$ & $\begin{array}{c}>1 \text { year } \\
(n=17 s 5)\end{array}$ & & \\
\hline \multirow{2}{*}{ Age (year) } & $60-70$ & $63(31.70)$ & $136(68.30)$ & 199 & \multirow{2}{*}{0.048} \\
\hline & $>70$ & $12(23.53)$ & $39(76.47)$ & 51 & \\
\hline \multirow{2}{*}{ Gender } & Male & $48(28.60)$ & $120(71.40)$ & 168 & \multirow{2}{*}{0.498} \\
\hline & Female & $27(32.90)$ & $55(67.10)$ & 82 & \\
\hline \multirow{2}{*}{$\begin{array}{l}\text { Partnership } \\
\text { status }\end{array}$} & $\begin{array}{l}\text { Having } \\
\text { partner }\end{array}$ & $64(31.50)$ & $139(68.50)$ & 203 & \multirow{2}{*}{0.017} \\
\hline & Others & $11(23.40)$ & $36(76.60)$ & 47 & \\
\hline \multirow{2}{*}{ Family type } & Nuclear & 19(14.39) & 113(85.61) & 132 & \multirow{2}{*}{0.04} \\
\hline & Joint & $56(47.45)$ & $62(52.55)$ & 118 & \\
\hline \multirow{2}{*}{ Family size } & $\leq 5$ & 19(14.39) & 113(85.61) & 132 & \multirow{2}{*}{0.04} \\
\hline & $>5$ & $56(47.45)$ & $62(52.55)$ & 118 & \\
\hline \multirow{2}{*}{ Education } & Illiterate & $48(31.80)$ & $103(68.20)$ & 151 & \multirow{2}{*}{0.048} \\
\hline & Literate & $27(27.30)$ & $72(72.70)$ & 99 & \\
\hline \multirow{2}{*}{$\begin{array}{l}\text { Working } \\
\text { status }\end{array}$} & Yes & $47(34.60)$ & $89(65.40)$ & 136 & \multirow{2}{*}{0.046} \\
\hline & No & $28(24.60)$ & $86(75.40)$ & 114 & \\
\hline \multirow{2}{*}{$\begin{array}{l}\text { Monthly family } \\
\text { income (Taka) }\end{array}$} & $\leq 6000$ & $39(36.10)$ & $69(63.90)$ & 108 & \multirow{2}{*}{0.036} \\
\hline & $>6000$ & $36(25.40)$ & $106(74.60)$ & 142 & \\
\hline \multirow{2}{*}{$\begin{array}{l}\text { Behavior of } \\
\text { family } \\
\text { member }\end{array}$} & Good & $64(31.10)$ & $142(68.90)$ & 206 & \multirow{2}{*}{0.425} \\
\hline & Not so good & $11(25.00)$ & $33(75.00)$ & 44 & \\
\hline \multirow{2}{*}{ Drug addiction } & Yes & $24(22.20)$ & $84(77.80)$ & 108 & \multirow{2}{*}{0.019} \\
\hline & No & $51(35.90)$ & $91(64.10)$ & 142 & \\
\hline \multirow{2}{*}{$\begin{array}{l}\text { Having } \\
\text { cultivated land } \\
\text { (in decimal) }\end{array}$} & $\leq 100$ & $44(31.20)$ & $97(68.80)$ & 141 & \multirow{2}{*}{0.19} \\
\hline & $>100$ & $31(28.40)$ & $78(71.60)$ & 109 & \\
\hline Total & & $75(30.00)$ & $175(70.00)$ & 250 & \\
\hline
\end{tabular}

Table 2: Distribution of health-related characteristics by genders of elderly, $(\mathrm{N}=250)$. Note: ${ }^{*}$ Only those diseases were shown in the table prevalence of which was exceeds $5 \%$ in the total samples. The numbers inside the parenthesis indicate the percentages.

\section{Bivariate analysis}

In bivariate analysis, the Chi-squared $\left(\chi^{2}\right)$ test was applied to determine whether there is a significant association between disease suffering duration and other characteristics of the elderly and the results are presented in Table 3. The results revealed that among the factors, age $(\mathrm{p}<0.05)$, partnership status $(\mathrm{p}<0.01)$, family type $(\mathrm{p}<0.05)$, family size $(\mathrm{p}<0.05)$, education $(\mathrm{p}<0.05)$, working status $(\mathrm{p}<0.05)$, income $(\mathrm{p}<0.05)$, and drug addiction $(\mathrm{p}<0.01)$ were found statistically significantly associated with disease suffering duration.

The disease suffering duration was classified into two types, viz., short duration ( $\leq 1$ year), and long duration ( $>1$ year). The results showed that most of the elderly $(70.00 \%)$ were suffered from long duration diseases and higher percentage respondents were found

Table 3: Association between disease suffering duration, and socioeconomic and health factors. Note: The numbers inside the parenthesis indicate the percentages.

\section{Multivariate analysis}

\begin{tabular}{|c|c|c|c|c|c|}
\hline \multirow{3}{*}{$\begin{array}{l}\text { Independent } \\
\text { variables }\end{array}$} & \multicolumn{5}{|c|}{ Disease suffering duration $(Y)$} \\
\hline & \multirow{2}{*}{$\begin{array}{c}\text { Coefficient } \\
(\beta)\end{array}$} & \multirow[t]{2}{*}{ SE of $(\beta)$} & \multirow{2}{*}{$\begin{array}{c}\text { Odds } \\
\text { Ratio (OR) }\end{array}$} & \multicolumn{2}{|c|}{$95 \% \mathrm{Cl}$ of $\mathrm{OR}$} \\
\hline & & & & Lower & Upper \\
\hline 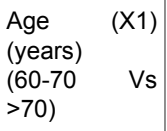 & -0.059 & 0.405 & $0.943^{\star *}$ & 0.427 & 2.085 \\
\hline
\end{tabular}




\begin{tabular}{|c|c|c|c|c|c|}
\hline $\begin{array}{l}\text { Partnership } \\
\text { status (X2) } \\
\text { (Having } \\
\text { partner Vs } \\
\text { otherwise) }\end{array}$ & 0.580 & 0.438 & $1.786^{\star *}$ & 0.756 & 4.217 \\
\hline $\begin{array}{l}\text { Family types } \\
\begin{array}{lr}\text { (X3) } & \text { (Single } \\
\text { family } & \text { Vs } \\
\text { Joint) }\end{array}\end{array}$ & -0.137 & 0.327 & $0.872^{* \star *}$ & 0.459 & 1.656 \\
\hline $\begin{array}{l}\text { Family size } \\
(X 4)(\leq 5 \mathrm{Vs} \\
>5)\end{array}$ & -0.551 & 0.318 & $0.577^{\star \star}$ & 0.309 & 1.076 \\
\hline $\begin{array}{l}\text { Education } \\
\text { (X5) (Illiterate } \\
\text { Vs Literate) }\end{array}$ & 0.518 & 0.345 & 1.679 & 0.854 & 3.301 \\
\hline $\begin{array}{l}\text { Currently } \\
\text { working (X6) } \\
\text { (Yes Vs No) }\end{array}$ & 0.560 & 0.334 & $1.750^{\star \star *}$ & 0.909 & 3.370 \\
\hline $\begin{array}{l}\text { Monthly } \\
\text { family income } \\
(X 7) \quad(\text { Taka) } \\
(\leq 6000 \text { Vs } \\
>6000)\end{array}$ & -0.499 & 0.338 & $0.607^{\star * *}$ & 0.313 & 1.178 \\
\hline $\begin{array}{l}\text { Drug } \\
\text { addiction }(\mathrm{X} 8) \\
\text { (Yes Vs No) }\end{array}$ & -0.580 & 0.323 & $1.297^{\star * *}$ & 0.542 & 1.678 \\
\hline
\end{tabular}

Table 4: Results of binary logistic regression analysis. Note: Vs: Versus; ${ }^{* *} \mathrm{P}<0.05 ;{ }^{* * *} \mathrm{P}<0.01 ; \mathrm{CI}$; Confidence Interval.

Impacts of the associated factors on 'disease suffering duration' are identified by the binary logistic regression analysis and the results are presented in Table 4 . The binary logistic model identified that the respondents' age, partnership status, family type, family size, working status, income, and drug addiction were the significant predictors of disease suffering duration. It is found that long duration disease suffering was $5.70 \%$ (OR: 0.943, 95\% CI: 0.427-2.085) lower risks among the elderly aged at most 70 years as compared to the elderly whose age more than 70 years. The life partner less elderly were faced 1.786 (OR: 1.786, 95\% CI: 0.756-4.217) times more risk of having long duration diseases suffering compared to the elderly with having life partners. The risk of having long duration disease suffering $12.80 \%$ (OR: $0.872,95 \%$ CI: $0.459-1.656$ ) and 42.3\% (OR: 0.577, 95\% CI: $0.309-1.076$ ) less among the elderly living with joint family and having family member more than 5 , respectively. The respondents were found 1.75 (OR: 1.750, 95\% CI: 0.909-3.370) times higher risk of suffering long duration diseases who were separated from any kind of formal works compared to them who were currently involved any types of works. The risk of having long duration disease sufferings were also found $39.30 \%$ (OR: 0.607, 95\% CI: 0.313-1.178) higher among the elderly who have had less family income. In case of the drug addiction, the elderly who used any type of drug were 1.297 (OR: 1.297, 95\% CI: 0.542-1.678) times higher risk to be suffered from long duration diseases compared to the elderly who did not use drug.

\section{Discussion}

Aging is the ultimate reality of human life and one of the natural and unavoidable demographic processes. The developed countries realize this reality and evolve policy instrument in the form of the social security as well as care for the elderly through institutions like old homes, geriatric hospitals, old recreation center and many other public and private care systems. But, still now these policy instruments are at a primary stage in developing countries like Bangladesh. Most of the developing countries are young in terms of the population age structure and they are becoming older more rapidly than the industrialized nations. These changes in the population distributions may have the serious implication and requires a special attention for the elderly. In view of gradual increment of the number of elderly population in Bangladesh, they are becoming more vulnerable in the society. Most of the elderly suffer from various types of chronic health complications. But, very little support is available through the public and governmental programs for the welfare of the elderly. Through the findings of this study, a clear picture is presented in context of diseases prevalence and disease suffering duration of the elderly in the rural areas of Bangladesh.

In this study, it is found that almost all elderly (84.40\%) were suffered from different types of diseases and of them $70 \%$ elderly were suffering long duration diseases ( $>1$ year). Similar results were observed in the previous studies [21,25] In case of disease types, around half of the total elderly were suffered from insomnia (45.97\%) and eye problems (44.55\%). This finding slightly supported to the findings of Kalam and Khan [21] but directly opposite to the findings of Khanam et al [25] that arthritis is the most common health problem among the elderly in Bangladesh. Traditionally older adults in Bangladesh depend on their family members and they provide companionship, food, shelter and the healthcare services. But, rapid socioeconomic and demographic transformation, mass poverty, declining social and religious values, influence of western cultures, and other factors have broken down the traditional systems. These socioeconomic transformations will certainly put the welfare of the elderly in jeopardy. This study showed that, the elderly were bearing their treatment costs by themselves $(43.60 \%)$ and by their sons $(47.20 \%)$, respectively. Elderly with self-treatment costs bearing are increasing; on the other hand, son's treatment cost bearing decreasing. This is due to the breakup the traditional family's structure $[21,26]$. Received accompany when they were sick, needs of the elderly shown the different patterns in the previous studies' findings [21,27]. Generally, elderly prefer to live in family atmosphere and kinship bond. But, they suffer physically and psychological problems when these traditional family atmosphere and kinship bond are broking and this will support the energy of affecting them long term disease suffering. In this study, it has been observed that, long term diseases were observed more prevalent among the elderly in a single or nuclear family with family members less than 5 . This findings is consistent with the findings of others studies $[15,27]$.

This study evidently identified the disease suffering duration increasing with the increasing of age. Long duration diseases are also observed and these are more established among the elderly who are currently involved in forms of work. In this regard, some studies have identified that disease and the disease suffering duration both were increasing day by day and presently workless elderly were more sufferers compared to the elderly who were involved any type of works $[8,21,27]$ The long duration disease suffering are also observed more common among currently partner less elderly. Elderly with having a partner are able to share their sorrows and happiness and enjoy their better healthy lives than that of partner less elderly. In fact, the findings are consistent with the findings to the previous studies $[21,27]$. 
The mail limitation of this study is that it was a community based survey and performed by one investigator. Again, it is limited to one union of the Northern region of Bangladesh due to the time, money manpower constrains. Moreover, all the diseases were recorded as perceived by the elderly and no diagnostic and clinical tests were done to confirm or refute the same diseases. Many of the elderly respondents try to hide their real situation on some aspects.

\section{Conclusion}

The study identified the risk factors of disease suffering duration and disease prevalence among the elderly in the rural areas of Bangladesh. Most of the elderly were suffered from different types of long term diseases and majorities were suffered from multiple diseases. Among the diseases of the respondents, Insomnia was found highest followed by the eye problem, joint pain and so on. The sons of the elderly were found to be most responsible persons who bear the treatment costs and give accompany when they were sick. In most of the cases, the respondents did not visit the registered doctors. The elderly aged 70 and above, lived in the single family, with less family members, currently workless, low family income, and drug addicted were more sufferer of the long term diseases. The study results have some policy implications for the elderly, especially living in the rural areas in Bangladesh. Urgent action is needed to improve their quality of life through the reduction of disease prevalence and disease suffering duration. Government and non-government efforts should aim to increase their health care services. We analyzed data from three villages of a union of Pabna District, Bangladesh. To identify the risk factors that influence the disease suffering duration of the elderly, future research should evaluate larger datasets and wider range of factors.

\section{References}

1. UN. World Population Ageing Report 2013 Department of economics and social welfare, 2013; United Nations (UN), New York, USA.

2. Nath DC, Islam MN (2012) Measuring Aging as a Function of Population Momentum: An Application with Bangladesh Population. International Journal of Statistical Sciences 12:53-70.

3. BBS. Population Census 2011 Preliminary Report. Bangladesh Bureau of Statistics (BBS), 2013; Ministry of Planning, Dhaka, Bangladesh

4. PRB. World Population Data Sheet 2014 Population Reference Bureau (PRB), 2014, Washington DC, USA.

5. Haque MJ, Alam MR (2003) Health Problem of the Geriatric People: A Community based Study in a Rural Area in Bangladesh. Journal of Teachers Association 16: 15-19.

6. Khan MN, Mondal MNI, Hoque N, Islam MS, Shahiduzzaman M (2014) A Study on Quality of Life of Elderly Population in Bangladesh. American Journal of Health Research 2: 152-157.

7. Kowal P, Kahn K, Ng N, Naidoo N, Abdullah S, et al. (2010) Ageing and adult health status in eight lower-income countries: the INDEPTH WHO-SAGE collaboration. Glob Health Action 3.

8. Hossain MR (2005) Aging in Bangladesh and its population projection. Pak J Soc Sci 3: 62-67.
9. Ahmed SM, Tomson G, Petzold M, Kabir ZN (2005) Socioeconomic status overrides age and gender in determining health-seeking behaviour in rural Bangladesh. Bull World Health Organ 83: 109-117.

10. Mondal MNI, Ullah MMMN, Islam MR, Rahman MS, Khan MN et.al. (2015) Sociodemographic and Health Determinants of Inequalities in Life Expectancy in Least Developed Countries. International Journal of $\mathrm{MCH}$ and AIDS 3: 96-105.

11. Mondal MN, Shitan M (2014) Relative importance of demographic, socioeconomic and health factors on life expectancy in low- and lowermiddle-income countries. J Epidemiol 24: 117-124.

12. Mondal MNI, Shitan M (2013) Impact of Socio-Health Factors on Life Expectancy in the Low and Lower Middle Income Countries. Iranian J Publ Health 42: 1354-1362.

13. Mondal MN, Shitan M (2013) Factors affecting the HIV/AIDS epidemic: an ecological analysis of global data. Afr Health Sci 13: 301-310.

14. Khan MN, Mondal MNI, Alam MS, Rahman MS (2015) Risk Factors of Duration of Suffering from Long Term Diseases among the Elderly People in Rural Bangladesh. Indian Journal of Gerontology 29:170-176.

15. Khan HTA, Leeson GW (2006) The demography of aging in Bangladesh: a scenario analysis of the consequences. Hallym International Journal of Aging 8: 1-21.

16. Rowshon AHM (2012) Ageing and Health: How far Bangladesh is Prepared? J Shaheed Suhrawardy Med Coll 4: 1-2.

17. Gordon M (2000) Problems of an aging population in an era of technology. J Can Dent Assoc 66: 320-322.

18. Alam K, Mahal A (2014) The economic burden of angina on households in South Asia. BMC Public Health 14: 179.

19. Seidler AM, Pennie ML, Veledar E, Culler SD, Chen SC (2010) Economic burden of melanoma in the elderly population: population-based analysis of the Surveillance, Epidemiology, and End Results (SEER)--Medicare data. Arch Dermatol 146: 249-256.

20. Begum MS (2007) Geriatric Health Problems and Health Care Seeking Practice Among Elderly People Attending One Selected Geriatric Hospital. Bangladesh J Physiol Pharmacol 23:20-24.

21. Kalam SM, Khan HTA (2006) Morbidities among older people in Bangladesh: Evidence from an aging survey. BRAC University Journal 3:75-83.

22. Tareque MI, Begum S, Saito Y (2013) Gender differences in disabilityfree life expectancy at old ages in Bangladesh. J Aging Health 25: 1299-1312.

23. Cherry N, Chowdhury M, Haque R, McDonald C, Chowdhury Z (2012) Disability among elderly rural villagers: report of a survey from Gonoshasthaya Kendra, Bangladesh. BMC Public Health 12: 379.

24. Chan YH (2004) Biostatistics 202: logistic regression analysis. Singapore Med J 45: 149-153.

25. Khanam MA, Streatfield PK, Kabir ZN, Qiu C, Cornelius C, et al. (2011) Prevalence and patterns of multimorbidity among elderly people in rural Bangladesh: a cross-sectional study. J Health Popul Nutr 29: 406-414.

26. Rahman M, Islam MM, Islam MR, Sadhya G, Latif MA (2011) Disease Pattern and Health Seeking Behavior in Rural Bangladesh. Faridpur Med. Coll J 5: 32-37.

27. Munsur AM, Tareque I, Rahman KMM (2010) Determinants of Living Arrangements, Health Status and Abuse among Elderly Women: A Study of Rural Naogaon District, Bangladesh. Journal of International Women's Studies 11: 162-176. 